\title{
From Natural to Artificial Selection: A Chaotic Reading of Shelagh Stephenson's An Experiment with an Air Pump (1998)
}

Khalid Ahmad Yas*, Arbaayah Ali Termizi, Rosli Talif, Hardev Kaur

University Putra Malaysia, Serdang, Selangor, Malaysia

Corresponding Author: Khalid Ahmad Yas, E-mail: khalidyas2009@yahoo.com

\section{ARTICLE INFO}

\section{Article history}

Received: July 29, 2017

Accepted: October 24, 2017

Published: January 05, 2018

Volume: 7 Issue: 1

Advance access: December 2017

Conflicts of interest: None

Funding: None

\begin{abstract}
The paper aims to utilise chaos theory as a methodology and perspective to analyse Shelagh Stephenson's science drama An Experiment with an Air Pump thematically and structurally. It is highly pertinent to mention here that the discovery of the DNA structure in 1953 by Watson and Crick coincided with the development of a new paradigm shift in science, chaos theory. The discovery of the DNA structure, on the other hand, led to the birth of the science of genetics which reached its peak in the late 1990s when Human Genome Project was completed. Theatre did not stand aloof from this radical shift. Mapping human genome might lead to appalling ethical dilemmas. Topics related to the cold war and nuclear-bomb were replaced with ones quoted from biology, genetics and cloning. Stephenson's play brings to light the danger of turning from natural to artificial selection as science, now, has access not only to the DNA structure but also how to manipulate it. The drama's extensive debate focuses mainly on the risk of genome-related discrimination.
\end{abstract}

Key words: Thermodynamics, Entropy, Chaos Theory, Self-organization, Genetics, Artificial Selectio

\section{INTRODUCTION}

As the primary objective is to utilise chaos theory as a perspective and mythology, it is highly relevant to define the science of chaos focusing on key-shifts that softened the earth to this paradigm shift to emerge with a bird's eye view given to the theatre as a barometer of art and culture in society.

\section{The Story of Order and Chaos}

Since the dawn of humanity, Man tends to embrace order and discard chaos as a source of evil and ambiguity. Chaos, as Hayles (1990) explained, was "associated with the unformed, the unthought, the unfilled, [and] the unordered" (p.19). At this point, chaos had no link to order at all. Such a concept was supported highly by Newtonianism which presented a clock-like universe ruled by the immutable laws of cause and effect. This view makes our world predictable and finally controllable. It pervades all aspects of life and turns into a cult (Prigogine and Stengers, 1984). The discovery of the second law of thermodynamic and entropy in the 1850 s led to identifying chaos as an opposite to order. It is no longer that shapeless matter existed before the creation of the world. Thermodynamics and later Quantum Physics turned the spotlight from order to disorder. They shattered Western man certainty in Newtonian predictable and ordered worldview that reigned since the Enlightenment. They made chance, uncertainty and disorder functioning words to describe the world. They introduced disorder as the law of nature and promised nothing but purposelessness and pessimism (Tarnas, 1991).

Chaos theory, instead, upholds that there is an order in an apparent disorder. Chaotic systems are replete with order. It is only their erratic behaviour that makes them look chaotic to the casual observer. Chaos, as Hayles (1991) explains, is the study of "orderly disorder" (p.1). To Hayles (1991), there are two views towards chaos: first, the chaos that has "a deep structure of order encoded within it," and second chaos leads "to order, as it does with self-organising systems" (p.3). The first view is well revealed in Gleick's book Chaos: Making of a New Science (1987), and the second is well-presented in Prigogine and Stengers' book Order out of Chaos: Man's New Dialogue with Nature (1984). Gleick's book tackles key ideas like the butterfly effect, strange attractor and recursive symmetry. The butterfly effect, the essence of chaos, casts light on one of the key aspects of chaos: the unnoticeable minute changes in the input could lead to dramatic variations in the output. It is highly associated with the example of a butterfly beats its wings in the southern hemisphere could eventually affect weather in the northern one. Such a notion unveils how chaos works, how much of it is inherent in the fabric of nature and how our ability to predict is limited. The other two facets; strange attractor and recursive symmetry, 
are the tools used by chaologists to reveal the hidden order in seeming disorder. Prigogine and Stengers' book, on the other hand, lays emphasis and expounds the process of self-organisation: how chaos can produce order. It is a sort of internal process without any external intervention.

At this stage, chaos is recognised as a precursor and partner of order. It presents a world that combines both order and disorder in which Man is neither totally bound nor entirely free. It is no longer the dustbin into which we toss things we cannot understand. It is unquestionably a part if not the whole reality, and, like order, chaos has a structure, too. It also promotes a holistic, not reductionistic view towards life. Accordingly, everything in the universe is connected to everything else in one way or another. With such a middle ground it secures between order and disorder and between determinism and indeterminism, chaos theory widely spreads, and considerably utilised in various disciplines including cultural and literary domains.

\section{Theatre}

Theatre in general and science play, in particular, did not stand aloof from such a significant shift in science. Till the eighties, topics related to a nuclear bomb, cold war and physics were prevalent. It was the late nineties when theatre started to quote from biology and genetics. The common denominator, as Glaser (2003) states, is "the importance of responsible conduct on the part of the scientific community" (p.191). Stephenson's play brings to light the danger of shifting from natural to artifici 1 selection as Man, now, is not only able to access to the DNA structure, but also to manipulate it. Genetic engineering is quite capable of extending the natural selection to society. To Rothenberg (2011), such a topic "has become ingrained in popular culture, [and] its dramatic potential has been effectively realised in theatre." It still "generates both awe and fear." The promise of ending diseases is always "countered by the peril embodied in the discriminatory capacity of genetic essentialism" (p.407). Plays like Copenhagen, The Genius, After Darwin, Molly Sweeny and An Experiment with an Air Pump according to Barr (2006) have not only given theatre the privilege of being the place of the "substantive interaction between the hard sciences and the humanities," but also put forward the "questions about the public responsibility of the scientists and the nature of his or her pursuit" (pp.1-3). The quest for knowledge started with Dr Faustus becomes more ethically complicated in the modern age. The impact is no longer personal as it was with Faustus who hurt none but himself (Orthofer, 2002).

\section{METHOD}

This paper intends to utilise the two views towards chaos to analyse Stephenson's play thematically and structurally. While the first view of order encoded within is going to secure a methodological framework, the second of chaos that begets order will work to secure a theoretical one. Concepts like the butterfly effect, strange attractors and recursive symmetries will go hand in hand with ideas like the edge of chaos and self-organisation. The butterfly effect, the essence of chaos, is chosen to explain and underscore the inciting events that start the conflict and stimulate action to start. With their ability to attract, constrain and guide a system to paths they choose, strange attractors will help to show the thematic concepts that guide the line of action and compel it to follow a particular course. As they help chaologists to map out the order in seeming disorder by tracking self-similarities on different levels of observation, recursive symmetries will be employed to reveal the order in appearing chaotic, fragmented plot. The play, in fact, is not built linearly rather interweaving more than one timeline. Action shuttles back and forth, and scenes from past and present are overlapped. Thus, one has to imitate chaologists by tracing recurring images to come up with the overall picture. Since it is more efficient and help to save time and avoid repetition, key-concepts of the theory will be elaborated on in the right place throughout the analysis part.

The impetus to adopt chaos theory stems from: first; the radical shift humanity has experienced from a Newtonian deterministic, reductionist and linear worldview to a chaotic, indeterministic, holistic and nonlinear one, more precisely from the absolute to the probability. Such a shift has questioned not only our firm beliefs but also reshaped the way we perceive the world. Second, the traditional approaches to literature, affected by the Newtonian model of a clocklike universe, have a limited capacity to absorb the kaleidoscopic dynamic structure of postmodern science drama. To Gillespie (2008); such a narrow view of analysis dominated most critical approaches for centuries has thwarted any attempt for diversity. It produces a sort of interpretations that are "too narrow to accommodate the full potential of literary expression" (p.3). Such approaches focus only "on a central idea, weighing the evidence, and balancing opposing views to arrive at a conclusion" (p.5). Chaos theory, instead, is able to furnish an intellectual background to read literature and to provide an alternative scope and terminology for literary interpretation.

The play is chosen: firstl, it reveals the postmodern turn in science plays from physics to biology. Secondly, science is not peripheral to the story; it is at the core of the drama. In her play, Stephenson interweaves the $18^{\text {th }}$-century quandary of cadavers with the $20^{\text {th }}$-century dilemma of stem cells and cloning. Through a bunch of humanists and scientist, she questions the role of science whether to change or to understand the world. Instead of being a means of liberation, science in the wrong hands can be a tool of oppression. Thirdly, the drama is not built around traditional structure or storyline where events put next to each other in a cohesive, unified plan governed by causality. They are presented in a disordered fashion. Thus, they appear chaotic to the casual spectator. The action does not move linearly throughout the play rather shuttles back and forth between two periods separated by a span of two centuries.

Overall, the radical shift in worldview, the way this drama is structured and the scientific idea it deals with all make it necessary to choose an approach stems from science itself to do the analysis. The paper does not imply in any way that 
other methods are false rather believe that adopting a holistic, dynamic approach for reading is quite crucial.

\section{AN EXPERIMENT WITH AN AIR PUMP: FROM NATURAL TO ARTIFICIAL SELECTION}

Shelagh Stephenson (1955-) is a playwright, scriptwriter, actress and a prolific radio dramatist. Her first play, The Memory of Water (1996), was a great success and garlanded with Olivier Award for Best Comedy. It brought Stephenson international recognition and later was adapted into a fil Before You Go in 2002. Her second drama An Experiment with an Air Pump (1998) was also an equal success. It was awarded the Peggy Ramsay Memorial Award. The play was inspired by Joseph Wright of Derby painting "An Experiment on a Bird in the Air Pump" in 1768. The painting, actually, was the butterfly effect that stirs the playwright's imagination. It provides her not only with characterisation or the title but also with the central argument. It portrays a broad spectrum of responses of folks joined to watch how an air pump can create a vacuum. The responses are quite diverse and suggestive: from scared young girls through an excited scientist and a pensive philosopher to an apathetic young couple. To Heffernan (2014), the painting reveals how modern science has seized not only the aura but also the supremacy and authority of religion. Science wonders start outshining the miracles of faith. Brigitte Glaser (2003) states that: Wright's painting has subtly "captured a transitional moment in the ethical and philosophical thinking of the eighteenth century" (p.189). It successfully merges the allurement of science and the sensibility of people during the age of reason.

Stephenson's play, premiered first at Hampstead Theatre in 1998, is a centuries-bridging work. It toggles between the dawning of two new eras; the birth of the Industrial Revolution and the modern age of biotechnology. It puts science at the core to address a cornucopia of provocative issues, science versus morality, ambition versus responsibility channelling in-between notions like the stereotypical image of women, the sanctity of human life and passion. The play interweaves two story lines taking place in the same house, Newcastle-on-Tyne. On the eve of 1799, Dr Fenwick's manor is full of activity: scientific experiments, an amateur farce and secret romance. Dr Fenwick is testing and discussing with his two assistants, senseless Armstrong and ethically sensitive Roget, how long a bird can stay alive without oxygen. On the periphery, there are his wife Susannah, his two daughters Harriet and Maria and Isobel, the housemaid. In the present world of genetics and scientific chaos, Ellen, molecular biologist, discusses with her redundant husband, Tom, a lucrative offer to work on pre-embryos. Meanwhile, the basement of the house uncovers a dark secret buried for 200 years stumbled on accidentally by the home surveyor, Phil.

Before setting sail, it is highly imperative to shed light on the opening scene as it sets the mood, the parallel structure and outlines both the conflict and characters. Ellen, a geneticist from the present, comes in dressing casually, while other dramatis personae are frozen in the tableau re-forming
Wright's painting. Ellen starts revealing her early infatuation with the painting. There is a "scientist at the heart of it, a scientist where [we] usually find God." Instead of "a saint or an archangel," we have a man at the centre of it: "his face, bathed in celestial light... beautified by his search for truth." While the ambition of girls her age was to marry handsome, famous men, hers was very simple, to be a god. Ellen, then, shifts to explain responses to the experiment drawn on the faces of characters. She starts with the terrified girls and then passes to the self-involved lovers. She stops for a while with the young scientist who looks indifferent to the bird's agony. He is quite captivated by science potentiality. She finally ends with the old man who is preoccupied with the repercussion of "the ethics of dabbling with life and death." He is quite anxious about "the old certainties... are slipping away from him, from his kind." To Ellen, as a scientist, the old man represents "the dead hand of caution." Ellen's ekphrastic explanation is closed by what held her most as a young girl of thirteen more than anything else; it is "the drama at the centre of it all." The moon shrouded in clouds set in the background of painting and the candlelight that is dipping and flickering all epitomise and symbolise "the power of light over darkness." Candlelight, actually, exemplifies the illuminating power of scientific reason to dissipate the darkness of ignorance and superstition (Prologue, pp.5-6).

Later, two stagehands come in helping Ellen to dress her $18^{\text {th }}$-century clothing and to join the tableau as it comes to life. She has transformed into Susanna: wife of an eminent $18^{\text {th }}$-century physician, Dr Joseph Fenwick. It is the Eve of 1799. Dr Fenwick, supported by Roget and Armstrong, is using the air pump to perform an experiment on Maria's pet bird. While her sister Harriet is quite fascinated by the experiment, Maria is apprehensive about the safety of her bird. Through the discussion, it is quite observable that men are educationally superior to women and science has replaced the spiritual relation inside the house. Susanna is totally ignored by her husband, and Maria's fears are not only ridiculed but also scorned by Armstrong who believes in keeping children "away from fireplace and women away from science" (Prologue, p.7).

Through Ellen, Stephenson alludes to the element of drama inside Wright's painting. Such a feature has worked as the butterfly effect that pushed her to write her second notable drama. The painting involves both laypeople and scientists, all of whom will be affected by the result of the experiment. It attempts to encapsulate a moment in time, a scientific one, which will radically impact future thought and understanding. In fact, the butterfly effect, discovered by Edward Lorenz in 1962, is no longer restricted to weather-forecasting as all dynamic systems, including us, exhibit great sensitivity to minute changes in initial conditions. To Arons and Richards (2015), a human being is not "a static thing:" he is a "process in motion" (p.169). Its appropriateness to a social or a literary context is quite similar to a scientific one. The dynamism of this phenomenon, according to Kellert (1994), is a suitable tool to reveal the role of some key historical events. History is full of examples of minor events "led to momentous and long-lasting changes in the course of 
human affairs" (p.5). To Marcelo Alonso (1990), it is very likely that certain "inventions, discoveries, revolutions, etc. may result in major changes" (xvii). Dramatic changes, as David Steenburg (1991) argues, do not need "big causes" to happen at all (456)."

Briefly speaking, the opening monologue provokes two essential points: the increasing secularisation and the intoxication of discovery. To Stephenson, the main reason of increasing secularisation is the absence of religion. People now turn to science for answers (Barr, 2006). Shaffer (1998) states openly that science "has taken the place of both theology and philosophy" in answering our most pressing questions about the origin, purpose and the end of life (p.2). What makes Ellen enthusiastic about the painting is what makes Stephenson worried. It is the ethical dilemma; the God-like authority practised by scientist what captures Stephenson's attention the most. The play, as Kazzazi (2014) proposes; questions and discusses "whether science is a menace to mankind or mercy? Is the scientist a secular saviour or a demonic annihilator? Can future be envisaged as utopia or dystopia"? (p.3)

To give the audience the opportunity to peek at the two families, the theatrical time machine moves back and forth between 1799 and 1999 represented respectively by scenes $\mathrm{i}$ and ii. Both years are highly symbolic. We stand on the thresholds of new coming centuries. There will be a tremendous progress in medicine of the $19^{\text {th }}$-century and genetics of the $21^{\text {st }}$-century. People have to face new challenges the new centuries are about to bring. The ambitious doctor and his two assistants are fully engaged in the prearrangement for the local Literary and Philosophical Society. Fenwick is discussing with Roget and Armstrong the suggestions and recommendations for the New Year lectures. He wants to make it something "worthy of the past and fired by visions of the future" (1.1.10). At the background, his two daughters squabble, his alcoholic wife keeps lamenting negligence, and the mob continues rioting over the rising price of fish. The sounds of glass-breaking and screaming outside the house make Fenwick feels thrilled. They are the sounds of change and revolution. The playwright, here, juxtaposes the spirit of scientific progress embodied by Fenwick and that of the age represented by the mob. It is a critical moment as it is going to witness the birth of change. Two centuries later, the house is occupied by Tom, a redundant professor of English literature and his wife Ellen, a geneticist. They are considering a lucrative offer brought by Ellen's old colleague Kate to work for the pre-embryos research facility. Tom has some serious moral qualms about it. Simultaneously, they are in dire need to get rid of the house. It is quite old and "it just eats up money" (1.2.26). As tension proceeds, they become obsessed with human bones found in a box by Phil, the building surveyor. The audience is brought again to $18^{\text {th }}$-century speculating over the unfortunate person who ends in this box. Who is the poor bird enmeshed in human-made air pump?

As mentioned earlier, chaos theory allows examining ordered patterns in a chaotic activity through two main tools: strange attractors and recursive symmetries. The only difference is that strange attractors deal with certain points. They cannot show chaologists how these patterns of order emerge, while recursive symmetries can. Scientists' primary focus is on identifying the iterative patterns on different scales. In doing so, they will be able to get the overall picture of these pockets of order in a chaotic activity (Hayles, 1991). Strange attractors, simply speaking, act as a magnet that attracts the system to a certain point. While Rossi (1989) and Argyros (1991) regard them as the best conceptualisation of human thoughts, theorists M. J. Wheatley (1992) deem them as an expression of meaning in one's life: the search for an attractor resembles the search for meaning. They can work as indicators of life's purposefulness. In physical domain, attractors take the form of physical properties, but in the human sphere, they take the form of dreams, desires, emotions...etc. Thus, determining their meaning can help much in determining human behaviour which is not entirely random but intricately ordered. In a piece of literature, according to Parker (2007), their significan e lies in connecting "form with content." They encompass motives that "concurrently attract and repel the writer" (p.28). In this play, the main attractor is the intoxication of discovery, the rapture of Eureka moment and the excitement of watching "frontiers tumbling before science's merciless deconstruction" (Prologue, 6). The main characters this section intends to discuss are Thomas Armstrong from 1799 story and Kate and Ellen from the 1999 story. According to Barr (2006), some of them are the real "incarnation of Faustus at his worst" (p.123).

Armstrong is a true picture of an unprincipled, corrupt scientist. He is a ruthless cunning physician. His only obsession is anatomy, more accurately freak anatomy. Fenwick's opinion of him at the beginning of the play as a "clever young bastard, but cold of heart" presents Armstrong as a cold, pitiless, self-serving opportunist (1.3.40). He seduces a hunchbacked serving girl, Isobel, and ruins her life just to have a chance to examine her deformity. He tells her many romantic things. He calls her beautiful, gives her necklace and a book of poetry. He kisses her passionately till he gets "her into the sack" (2.3.68). As she learns his real motive, Isobel runs to write her suicide note and hangs herself. While she is fi hting for the last gasps and her "heels flutter almost imperceptibly," Armstrong finishes the job by smothering her with his hand (2.5.74). He reveals how far an unscrupulous scientist could go. He looks at Isobel as an object to be examined scientificall. His fascination with her is a sort of sexual delight mixed with an unquenchable desire for power. He informs Roget that he will make her take off all her clothes, so he can enjoy examining "her beautiful back in all its delicious, twisted glory." He confides him that the first time he saw her, he got an erection. To freak Armstrong, discovery and sex, Eureka and ejaculation moments are the same: all are "arousing" (2.3.68). Conversely, Roget is horrified as he discovers Armstrong and Dr Farleigh, an offstage character, are looking for possible cadavers before even they actually die. Armstrong tells him that they have got their "eyes on an undersized fellow, about three foot tall. He's not at all well. He'll not see out the winter" (2.2.57). He justifies their action on the ground of advancement in the field of anatomy. To Armstrong, "discovery is neutral." Issues like 
"ethics should be left to philosophers and priests." It is quite vital to dig up corpses if they want "to totter out of the Dark Ages." He stated it clearly that he never had a moral qualm in his life, because "it would be death to science" if he did (2.2.57)

Kate, on the other hand, is a geneticist and Ellen's close friend. She is a careerist and an independent character. Like Armstrong, she firmly believes that science is morally neutral. She is sent by the institution she works for to persuade Ellen to take the offer. Her only obstacle is Tom, Ellen's husband, who has serious moral qualms concerning the offer. To Kate, stem-cells are only a cluster of undifferentiated cells, to Tom, they are a fetus. Ellen is torn between her husband's moral misgivings and her friend's rewarding offer. She is pulled and pushed in this dispute throughout the whole play. Tom and Phil believe that genetic intervention is a serious threat. It is a real danger not only for those who are socially susceptible but also for those are who outside the boundaries of normality. To Phil, Kate's project aims to see people like his schizophrenic uncle Stan selectively exterminated. Tom directly accuses Kate of being elitist. She cannot "understand the world at all" as she does all her "experiments in a vacuum" (2.4.72). The reference made to vacuum alludes to the air pump. The moment modern science succeeded in creating a vacuum, it stepped far away from ethics to pursue ends only. Kate cannot see where the problem is! She cannot understand why discarded embryos cannot be used to identify genes responsible for schizophrenia or cancer. Such genes can be quickly eliminated by "gene therapy in the womb" (1.2.32). Schizophrenia, to Tom, "is not a finite quantifiable thing." It is a state of mind varying considerably between creative powers and paralysing confusion. It cannot be "swat[ted] like a fly" (2.4.72)

To conclude, the three characters cannot resist the allure and enticement of discovery. Its glamour entirely consumes them. Armstrong and Kate are completely devoid of any sort of moral considerations. While cadaver is only meat for Armstrong, stem cells are just a cluster of cells for Kate. Armstrong anxiously waits for winter to see sick people drop dead like flies. Corpses become too cheap: "they're two a penny" (2.2.60). He is ready to do anything: to seduce, to hunt down dying people or even to murder. Kate, equally, is ready to dissect her mother if she can secure her an answer. Though she does not kill literally, she already promotes parental eugenic decisions. Unlike immoral weird Armstrong, Kate is simply amoral. Ellen does not believe that "science is value free." However, she fails to resist and takes the Faustian bargain. She tells Tom that science "is too exciting. I can't resist it, basically. It wasn't an intellectual decision. It was my heart." To her, science is not a job; it is an "urge to pursue, it is passion...Actually, it's more than that. It's sexy" (2.4.71). Due to the weathering romance, six miscarriages and the biological clock that ticks loudly, Ellen is in dire need to set a new attractor. Being without one is similar to be lost in boundless space. In a nutshell, the job offer is too enticing to refuse.

The question of whether a scientist can kill or not is answered alarmingly. Human bones found in the basement serve as a warning of what could happen if science left unguarded. Isobel, the looming possibility of science, has lost parts of the ribcage and vertebrate. Tom becomes very uncomfortable as Kate explains that students of medicine might have used Isobel's body for research. In ancient times, students of medicine used to act as grave robbers. The bottom line here is that students in the past, who led the way in human anatomy, are not quite different from stem-cell researchers of today. What makes Tom so worried is the market-driven culture. Such critical information might fall into the wrong hands, i.e. private health companies, insurance companies or mortgage lenders. To Barr (2006); "invoking the second law of thermodynamics as a theatrical metaphor is a strategy" playwrights, like Stoppard and Stephenson, "have found extremely effective," in particular with "science plays that express concern" about the morality and responsibility of a scientist towards his discovery (p.79). Ellen asserts to Tom the fact that "once you know something, you can't unknow it" (2.4.71). It implies that once discovery is reached, it is quite difficult to retake it. The second law, as Barr (2006) explains, serves here as "a handy metaphor for the irreversibility of human thought and progress" (p.85). Its implication is quite shocking in particular with scientists who have no moral qualms, like Armstrong and Kate.

Similarly, Phil believes that such scientists will lead humanity to the apocalypse of human cloning as science has the potentiality to become debased by either the marketplace or by those who wish to perfect human race. One day we might come across a Gene Shop around the corner, or we might have, as described by Phil, "a little plastic card with [our] DNA details on [it]" (2.2.56). Empowering genetic engineering, according to Tom, will ultimately generate a Health Underclass. As the poor people of the $18^{\text {th }}$-century were the collateral damage of Adam Smith's economics, modern people are quite liable to be the collateral damage of free trade policies and globalisation. Kate declines Tom's query whether or not she is interested in developing an A-bomb. Such a question jogs our memory of the high price humanity has paid for such an invention. To Heffernan (2014): killing thousands of people "is a long way from experimenting with embryos or with the life of a single bird - even a rare cockatoo" bird (p.9).

One of the significant contributions of the science of chaos is its comprehensiveness. It is typically a holistic science aiming to study how the interaction between parts participates to the functioning of the whole. To chaologists, a system reveals a chaotic behaviour cannot be reduced to its primary components. In doing so, the view of how system functions will be significantly distorted. Recursiveness or self-similarity is the tool scientists utilise to understand the evolution of a chaotic system. To Galatzer-Levy (1995), such a device exhibits that chaotic systems involve "structures that repeat basic features on several different levels of observation" (p.1085). According to Remer (2003), they "repeat themselves, not exactly, not perfectly, but still enough to be recognisable even on different scales" (pp.12-13). Equally important, such recursion also informs scientists that chaotic systems have continuity. They tend to carry the orig- 
inal order throughout all different levels of observation. Any tiny change will pass quickly throughout the whole system. Hence, like scientists who look for recursive symmetries to map out the order in a chaotic system, we attempt here to trace the recurring images in both narratives to expose order in seeming chaotic overlapped structure of the play.

Stephenson builds her drama in the form of recursive symmetries or self-similarities repeatedly emphasising the sanctity of human life versus scientific progress, and whether science should be utilised to change or understand the world. The action does not move linearly rather bouncing back and forth between the two periods. However, to come up with the overall picture, one has to imitate chaologists by tracking self-similarities or recurring images. The play is contrived in this way: the prologue, set in the form of a museum educator, outlines the main ideas and provides an overriding structuring and thematic image. It is followed by two narratives alternating scenes between the Eves of 1799 and 1999 in the same house. Such a technique adopted allows recurring variation and comparison to take place. Both story lines are met in the final scene to present the play's final message. The two story lines are linked dramaturgically by Ellen and thematically through Isobel's dismembered body.

Stephenson employs a series of conflicts that oppose a resolution. Each one is portrayed through oppositional pairs to present different possible readings. Like people in Wright's painting whose responses to bird's ordeal varying from a victimised subject to an interesting curiosity; characters' view towards right and wrong is mainly based on what actually matters most. Barnett (2006) comments that: instead of "reducing the possibilities to a single truth," the playwright tries "to create a vast array of choices, a world of chaotic possibility” (p.207). Stephens's self-reflexive play with inter-spliced scenes from two different periods is not built on the logic of either/or but about both. It is a sort of logic promotes by chaos theory; how opposite things can coexist, and how different meanings can be elicited every time they clash. To Barnett (2006), such logic of antitheses of; "past and future, man and God, life and death, brain and heart," can help "inform the structure of the play and create its basic tensions" (p.208).

The double narratives assist the playwright to contrast and compare $18^{\text {th }}$-century dilemma of cadavers and that of the $20^{\text {th }}$-century, the genetic engineering. The experiment is different, but the moral misgivings are the same. Both periods are times of scientific revolution and social upheaval. The double frame is utilised deliberately to help audience not to be involved emotionally. It is quite popular technique usually used by socially aware writers. Progress in the play is not a forward move. Present and the past are not separable entities, and both have an impact on future. It is a reaction to the second law of thermodynamics and entropy that depict the universe as a one-way road: moving in one direction from order to disorder (Zencey, 1991). In Act I, Scene iii, Isobel and Armstrong are frozen in time while Tom and Ellen are talking about the corpse found in their basement. Such a method, of juxtaposing past present, is a distinctive feature of the 1990s science drama. The past is no longer a mere fi ure of speech for the present rather has its own separate entity.

The evolution of women in general and in science, in particular, is well-embodied by Fenwick's women on the one hand, i.e. Susannah, Harriet and Maria of 1799, and Ellen and Kate of 1999 on the other. Susanna-Fenwick disturbed relation is well- reversed in the modern story. Susanna, who is being taught to master needlework only, longs badly for attention (2.3.60-61). Ellen, her 1999 counterpart, is a top biologist, while her Husband Tom is only a redundant humanist. Tom, on the other hand, is to some extent a reflection of Susannah. He is forced to leave his work, while his wife wins a very lucrative job offer. He is quite afraid of being supported financially by her. Carby (2011) explains that man's need to be "the primary breadwinner is [something] ingrained and important” (p.27).

Scientists of the 1799 story are all male. Women have access only to writing, reading or painting. During any political or scientific conversations, they are either ignored or excluded (1.3.37-38). Harriet little invention of a bonnet puffing steam, which she designs to win her father's favour, is only smiled at. Fenwick, the propagator of the Enlightenment, is a firm believer in the male domain of life, and even, unfortunate Susannah, who favours Shakespeare to Newton, promotes that women's role is to pursue only artistic ambition. To her, Harriet's forward thinking and her dream to be a physician like her dad seem outrageous. Harriet, born ahead of her time, has no plan for marriage. She believes it is an end for everything she desires. In the drama they act for the family on New Year Eve, she chooses to play Britannia, a symbol of future and progress. However, she cannot escape the role imposed by society. She is a victim of her status. The naive Maria, on the other hand, is lucky enough to discover her absent fiancé s fickleness. He cannot even remember the colour of her eyes. Nonetheless, Ellen and Kate of the 1999 story have reversed the bad luck of the 1799 women. Both hold leading positions in the world of genetic engineering. The marginalised Susannah is morphed into Ellen, a hardedged geneticist whose work on stem cells has the potentiality to rock the world. Likewise, Harriet's abortive dreams are fulfilled through Kate. She is an eminent doctor who passionately wants to tear the world asunder "to see what it is made of" (2.4.71).

Recurrent images are quite obvious with men, too. Tom reaffirms Roget's views, and Phil echoes his fears. They represent the voice of reason against the unrestrained ambition of science. They believe that science should be utilised to understand not to change the world. Roget is the only character based on real historical fi ure Peter Mark Roget, the creator of Roget's Thesaurus. He serves as a secretary to a leading scientist, Dr Joseph Fenwick. To Barr (2006), Roget is the depiction of a "non-scientist embracing a scientific methodology in the organisation of language, as if borrowing the authority of science" (P.87). He believes that the "world is a web of connections and affinities" which is the essence of chaos theory (1.3.35). Things in the universe are highly connected to each other. Any simple change may initiate an uncontrollable chain reaction. He values Armstrong's 
ambition, but he is worried about his unquenchable desire for discovery. He believes cadaver is wrong and stalking sick and disabled people is disgusting. Tom is not pleased with Ellen's sweeping statement regarding stem cells at all. He explains that the great "James Joyce probably had a schizophrenia gene, his daughter certainly did. It's a continuum, at one end you get poetry and at the other confusion" (2.4.72). When she tells him how her heart beats faster as she receives the generous offer, he comments that her heart is not "just a pump" (2.4.70). It is an allusion to Wright's painting and a reminder of the difference between us and machines. Phil, who has faith in alien invasions and spontaneous combustion of people, perceives the implication of Ellen's talk immediately. His reaction is that: "well the whole thing's very dodgy, you don't know what you're dabbling in if you ask me" (1.2.29). When Kate starts explaining the possibility of eradicating "all sorts of things; Schizophrenia, manic-depression," Phil interrupts her as he immediately realises that people like his manic but creative Uncle Stan would cease to exist. Phil is exasperated as Kate does not know the man. She does not "know anything about what went on in his life, or what things meant to him" (1.2.32-33). Like Armstrong, humanitarian issues, to Kate, means death to scientific enquiry. Roget, Tom and Phil are united through Isobel. The pain Roget felt as he learns about Armstrong's hidden intention toward Isobel is similar to that of Tom and Phil as they light a candle for Isobel's disturbed soul.

As the play begins with a gathering around a frail bird, it ends with the same crowd but around the corpse of poor Isobel. In her casket, Isobel has taken "the place of the bird in the air pump" (2.5.77). While the bird lives through the experiment, the poor girl is not spared. Unlike the bird, Isobel is not deprived of oxygen, but of her thoughts, emotions and self-worth. She is utterly ruined as she learns she is a mere object for examination, more precisely a cadaver waiting for dissection. The message is delivered: there is no place among us for those who are socially and physically vulnerable. It is a new type of selection: an artificial one. Like the bird, Isobel's mangled body sparks a variety of responses: Tom feels a sort of responsibility, Phil lights a candle and Ellen portrays what happened to Isobel as "the equivalent of leaving your body for medical research" (2.2.56). Instead of an abstract, cold debate, the playwright deliberately presents an appalling wake-up image. The corpse is not a mere pile of bones; it is an individual with dreams, fears and a name. Her suicide note is a warning against what could happen if man continues to pursue science without any moral considerations. Isobel becomes a symbolic gauge for modern man's attitudes toward the dichotomy of science and morality.

To love and be in love is the strange attractor that sets the course of Isobel's short life. Margaret Ward (1995) likens the process to "a marble placed...on the inside of a bowl." No matter what, the marble "will inevitably move toward the bottom." The deeper the bowl, the more powerful is the attraction. Ward (1995) concludes "it is much harder to dislodge an object (or an individual) from its trajectory in a deep rather than a shallow basin" (P.633). Being outcast from the feast of life, the only option Isobel has is to commit suicide.
Butz's (1993) metaphor of chaos as anxiety may help to understand Isobel behaviour. She is involved in a situation she cannot comprehend: it is beyond her control. She cannot cope with the surroundings anymore. Even words, her sole infatuation, fail to define her agony. She openly confesses that her vocabulary is insufficient to portray her anguish. Her words cannot elucidate how fast her fall "from contentment to despair" has happened (2.4.73). To Ackerman (2006), although words prove insufficient to depict her agony, her mangled remains are able to do so!

Setting the drama on the cusp of two pivotal epochs, the playwright simulates a system operates on the edge of chaos, an area of maximum complexity and alteration. To Roger Lewin (1999), we live in the proximity of this area. As we try to cross this border, things become so unpredictable. Chaos will launch a long process of change and reorganisation which is one of the fundamental facets of complex dynamical systems. It is something inherent in chaotic systems to create new patterns as a response to the new state of the system. It is an opposite of the second law which preaches only an increase in disorder and disorganisation (Hall, 1991). At this critical point, according to Remer (2003), a chaotic system tends to reshape itself internally into a different pattern and start spontaneously creating new attractors that eventually "serve as opportunities for creative, functional change" (p.13).

At the beginning of the play; Fenwick is fascinated by the potentiality of science and the bright future of reaching "uncharted lands," at the end; he finds himself "groping blindly over the border in a fog of bewilderment." As midnight approaches, they all gather round Isobel's coffin. Isobel's sudden demise mutes Fenwick's optimism and enthusiasm. As he kisses her, he tells her that "the future looks less benign now, Isobel. We're a little more frightened than we were" (2.5.77). Instead of attending lectures to celebrate the arrival of a new century, Fenwick attends a funeral. He absorbs the lesson so well. Poor Isobel is not a bird, and human beings are not objects for examination. Even the angry mob is silent now. Every relation and every issue of science or politics are pushed aside to honour Isobel. The family is uncertain whether the unruly mob are celebrating or rioting now. None of them ventures to open the window. It symbolically refers that future is quite obscure and unpredictable.

Nevertheless, there is a glimpse of hope amid this morbid chaotic situation. Like any chaotic system, human beings are also able to reorganise and adapt against the hideous implication of thermodynamic entropy. According to the new science of chaos, as Hayles explains, self-organisation is quite possible. A system of high entropy can "engage in spontaneous self-organisation" (p.13). People, as Tomas Kacer (2007) states; "act according to their inner inclinations which are independent of these circumstances" (p.166). Similarly, Nick Ruddick (2001) reveals that postmodern science plays are still "concerned to show that there remains a right and wrong way for people- including scientists - to act, even though the structure of physical reality... has been revealed to be fundamentally indeterminate" (p.417). Fenwick admits that " pure objectivity is an arrogant fallacy...good science 
requires us to utilise every aspect of ourselves in pursuit of truth [and] sometimes the heart comes into it" (1.3.40). Likewise, Ellen makes a confession: science is not "value free... [or] morally neutral". She adds that "an exquisitely balanced formula is a poem". Tom responds that they are not entirely "different after all. Art and science, waves and particles, it's all the same thing" (2.4.71). To Barnett (2006), such reconciliation at the end of the play between conflic ing dichotomies suggests that that "morality and science can work in collaboration, not always in contradiction" (p.216). Tom's final words addressed to Ellen are quite suggestive and expressive. Tom invites Ellen to "start again. It could be exciting even. [...] Let's go and put the champagne in the fridge" (2.5.76). The dialogue between Tom, the humanist, and Ellen, the scientist, at the end of the play reveal that: like any chaotic system, human beings can reshape and adapt. They are highly capable of begetting order out of disorder and set new attractors.

\section{CONCLUSION}

As referred to above, the progress in genetics and the development of chaos theory as a new paradigm shift in science occurred concurrently during the late 1950s and early 1960s. During this period onwards, there is a growing social awareness that our world is inherently complex and chaotic. We are not isolated rather enmeshed in a complex interdependent system. Unfortunately, we keep manipulating nature and blurring the borders between the natural and the artificial. Modern technology allows us to harness enormous energy able to lead us to extinction. The science of chaos asserts that events in our environment occur not by apparent, large causes rather by obscure, tiny ones. Genetic engineering is an obvious example of these small events. The microscopic genes can determine macroscopic characteristics of a biological system. Conversely, genetic engineering can help to eradicate certain malignant diseases as it allows an access not only to the genetic material but also to change it. Through this analogy of promise and peril, Stephens' centuries-bridging drama tries to examine the problematic relationship between science and ethics. The play poses within questions like: is it right to play the Deity and impose order on a world inherently chaotic? Is it necessary to repeat the misfortune of our Edenic fathers or to copy the experience of Greek Prometheus? Equally, is it correct to go on pondering existence while we can exercise some power over this reality?

Through a bunch of humanists and scientists, Stephenson secures a forum for such topics and ethics related. Science to Stephenson is an emotional, cultural, religious and a political indicator of people's at a given period of time. It cannot be divorced from its context. The air-pump is not only a device able to create vacuum: it is an embodiment of an age mentality. It suggests that man, too, can now practice the life-giving or death-carrying role associated only with God. Phil and Tom are afraid of turning technology into a tool of oppression, not liberation. Genetic engineering is quite able to extend the natural selection to society. It is quite horrible when science becomes a surrogate god producing its own ethics. Armstrong and Kate reveal an inner human desire to practice God-like authority. The noble goal of eradicating fatal diseases will soon or later be corrupted by big business and commercial market. The culture of wealth and scientific elite cause these eminent scientists to succumb to scientific ambition. They are quite capable of "luring the best scientists away from pure, unmatched research into nefarious exploitive purposes" (Barr, 2006, p.123). The human genome, the grail of genetic engineering, might fulfil the dystopian visions of Mary Shelley, Aldous Huxley, H. G. Wells and Goerge Orwell. Prometheus, Faust, and Frankenstein are still haunting our imagination: how to control natural process and how to avoid unpredictable consequence.

Instead of an abstract debate, Stephenson presents a shocking image through the murder of Isobel and what she represents. In the play within a play performed to celebrate the advent of a new century, Isobel is given the role of sheep. She represents the past, the pastoral innocence, which is seen as idle, not ideal. She becomes a reminder of a serene, simple life choked by the smoke of progress. The play here presets inventory of what science has achieved and whether the price paid is worth it! The double narratives assist in comparing and contrasting. Instead of reducing the debate to a single truth, Stephenson presents a world of chaotic possibilities. Each opposing pairs reveal their attitudes whether science is morally neutral or not. The play closes with the same tableau it starts with; but, instead of a bird, we have Isobel. The firs tableau mimics the painting is natural, the second is startling. However, the play offers a glimpse of hope at the end. Like any dynamic complex system, man is able to reshape. Fenwick, as well as Ellen, admits that scientific objectivity is a fallacy. Science is not entirely morally-free. The heart should be given a role in this process. Like poetry, scientific equations cannot work well if they are not well-rhythmic. Such reconciliation between the two conflicting dichotomies at the end exhibits that science and ethics can work together. They are not always at war. The drama promotes what chaos theory preaches that opposing things can coexist together. Like the universe, we can renew from within and, like any chaotic system, we can switch between attractors and set new ones.

\section{REFERENCES}

Ackerman, Alan. "The Prompter's Box: Modern Drama's Allegories of Allegory." Modern Drama 49.2 (2006): 147-54.

Alonso, Marcelo, ed. Organization and Change in Complex Systems. New York: Paragon House, 1990. Print.

Argyros, Alexander. A Blessed Rage for Order: Deconstruction, Evolution, and Chaos. University of Michigan Press, 1991. Print.

Arons, Mike and Ruth Richards. "Two Noble Insurgencies: Creativity and Humanistic Psychology". The Handbook of Humanistic Psychology: Theory, Research, and Practice. (Eds.) Kirk J. Schneider, J. Fraser Pierson and James F. T. Bugental. SAGE Publications, 2015. pp.161176. Print.

Barnett, Claudia. "A Moral Dialectic: Shelagh Stephenson's An Experiment with an Air Pump." Modern Drama 49.2 (2006): 206-22. 
Barr, Kirsten Shepherd. Science on Stage: From Doctor Faustus to Copenhagen. Princeton University Press, 2006. Print.

Best, Steven, and Douglas Kellner. The Postmodern Adventure: Science, Technology, and Cultural Studies at the Third Millennium. New York: Guilford Press, 2001. Print.

Butz, Michael R. "Practical Applications From Chaos Theory To The Psychotherapeutic Process, A Basic Consideration Of Dynamics." Psychological Reports 73.2 (1993): 543-54.

Galatzer-Levy, Robert M. "Psychoanalysis and Dynamical Systems Theory: Prediction and Self Similarity." Journal of the American Psychoanalytic Association 43.4 (1995): 1085-114.

Gillespie, Michael Patrick. The Aesthetics of Chaos: Nonlinear Thinking and Contemporary Literary Criticism. University of Florida Press, 2008. Print.

Glaser, Brigitte. "Female Scientists/Women and Science New Characters and Themes in British Drama." Framing Women Changing Frames of Representation from the Enlightenment to Postmodernism. (Eds.) Sandra Carroll, Birgit Pretzsch and Peter Wagner. Max Niemeyer Verlag Tubingen, 2003. pp.189-206. Print.

Gleick, James. Chaos: Making of a New Science. New York: Penguin Group, 1987. Print.

Hall, Nina. Exploring Chaos: A Guide to the New Science of Disorder. New York: W. W. Norton \& Company, 1991. Print.

Hayles, N. Katherine. "Introduction: Complex Dynamics in Literature and Science." Chaos and Order: Complex Dynamics in Literature and Science. (Ed.) N. Katherine Hayles. Chicago: The University of Chicago Press, 1991. pp. 1-33. Print.

---. Chaos Bound: Orderly Disorder in Contemporary Literature and Science. Ithaca: Cornell University Press, 1990. Print.

Heffernan, James A. W. "Art, Science, and Sacrifice in the Experiments of Joseph Wright and Shelagh Stephenson." Representing Restoration, Enlightenment and Romanticism. (Eds.) Achim Hescher, Anja Müller, and Anke Uebel. Wiss. Verlag Trier, 2014. pp.115-125. Print

Kacer, Tomas. "I Am Britannia, the Spirit of Our Age": Time Shifting as a Study of the Idea of Progress in Tom Stoppard's Arcadia and Shelagh Stephenson's An Experiment with an Air Pump." Sbornik Praci Filozofické Fakulty Brněnské Univerzity 56.13 (2007): 157-67.

Kazzazi, Seyedeh Anahit. Scientific Progress: A Hope or an Illusion? How Post-War Science Playwrights Responded to This Dichotomy. Probing Boundaries: $6^{\text {th }}$ Global Conference, Session 9: Dramatic and Literary Expressions of Hope, Prague, Czech Republic, 14 ${ }^{\text {th }}$ March $16^{\text {th }}$ March 2014. Inter-Disciplinary.Net, 2014. Print.
Kellert, Stephen H. In the Wake of Chaos: Unpredictable Order in Dynamical Systems. The University of Chicago Press, 1994. Print.

Lewin, Roger. Complexity: Life at the Edge of Chaos. University of Chicago Press, 1999. Print.

Orthofer, M. A. "The Scientist on the Stage: A Survey." Interdisciplinary Science Reviews 27.3 (2002): 173-83.

Parker, Jo Alyson. Narrative Form and Chaos Theory in Sterne, Proust, Woolf, and Faulkner. Palgrave Macmillan, 2007. Print.

Prigogine, llya and Isabelle Stengers. Order out of chaos: Man's New Dialogue with Nature. Bantam Books, 1984. Print.

Remer, Roy. "Chaos Theory and Its Implications for Counseling Psychology." Chaos Theory and Counseling Psychology. University of Kentucky, Kentucky. 20 Feb. 2003. Web. 5 Jan. 2017. < https://www.google.com/\#q=Chaos+Theory+and+Its+Implications+for+Counseling+Psychology $>$.

Rossi, Ernest L. "Archetypes as Strange Attractors." Psychological Perspectives: A Quarterly Journal of Jungian Thought 20, no. 1 (1989): 4-15.

Rothenberg, Karen H. "From Eugenics to the "New" Genetics: "The Play's the Thing." Fordham Law Review 79.2 (2011): 407-33.

Ruddick, Nick. "The Search for a Quantum Ethics: Michael Frayn's "Copenhagen" and Other Recent British Science Plays." Journal of the Fantastic in the Arts 11.4 (2001): 415-31.

Shaffer, E. S. "Introduction: The Third Culture - Negotiating the "two cultures". The Third Culture: Literature and Science. (Ed.) Elinor S. Shaffer. Berlin: de Gruyter \& Co., 1998. pp.1-12. Print.

Steenburg, David. "Chaos at the Marriage of Heaven and Hell." Harvard Theological Review 84.04 (1991): 447-66.

Stephenson Shelagh. An Experiment with an Air Pump. New York: DSP, Inc., 2000. Print.

Tarnas, Richard. The Passion of the Western Mind: Understanding the Ideas that Have Shaped our World View. New York: Random House Publishing, 1991. Print.

Ward, Margaret. "Butterflies and Bifurcations: Can Chaos Theory Contribute to Our Understanding of Family Systems?" Journal of Marriage and Family 57.3 (1995): 629-38.

Wheatley, Margaret J. Leadership and the New Science: Learning about Organization from an Orderly Universe. San Francisco: Berrett-Koehler, 1992. Print.

Zencey, Eric. "Some Brief Speculations on the Popularity of Entropy as Metaphor." Metaphor and Symbolic Activity 6.1 (1991): 47-56. 